\title{
Molecular Cloning of MYMV Genome and Infectivity of Yellow Mosaic Virus in Green Gram Using Different Viral Transmission Tools
}

\author{
Ashwini Talakayala ${ }^{1,2}$, Veerapaneni Bindu Prathyusha ${ }^{1}$, Dhanasekar Divya ${ }^{1}$, \\ Srinivas Ankanagari ${ }^{2}$ and Mallikarjuna Garladinne ${ }^{1 *}$ \\ ${ }^{1}$ Plant Molecular Biology laboratory, Agri Biotech Foundation, \\ Rajendranagar, Hyderabad-500 030, India. \\ ${ }^{2}$ Department of Genetics, Osmania University, Hyderabad-500 007, India.
}

http://dx.doi.org/10.13005/bbra/2932

(Received: 08 September 2021; accepted: 21 October 2021)

\begin{abstract}
Mungbean yellow mosaic virus (MYMV) causes massive crop losses in green gram. MYMV is a member of begomovirus with bipartite genome comprising DNA-A and DNA-B components, which is transmitted by whiteflies. Cloning and preparation of infectious clone is very much essential for screening germplasm or transgenic material of pulse crops since viruliferous whiteflies may not be available throughout the year. In the current work, we have amplified rolling circle mediated viral genome of MYMV using F29 DNA polymerase. The amplified products was digested and cloned into the plant expression vector pCAMBIA2301. The cloned constructs was then transformed into Agrobacterium LBA4404 through freeze thaw method. Further, three viral transmission techniques including mechanical rubbing, Agroinfiltration and Agroinoculation, were employed for assessing the mosaic symptoms in green gram. The molecular confirmation through polymerase chain reaction (PCR) indicated that the yellow mosaic symptoms were formed due to infectivity of MYMV in the green gram.
\end{abstract}

Keywords: Agroinfiltration; Agroinoculation; F29 DNA polymerase; Yellow mosaic disease.

Yellow Mosaic Disease in greengram is caused by Mungbean Yellow Mosaic Virus (MYMV), devastating large acres of crops, particularly in tropical and subtropical countries ${ }^{1}$. The MYMV belongs to the Geminiviridae family and two isolates of MYMV were evolved in Indian sub-continent. The MYMV possesses a circular and single-stranded DNA genome encapsulated with icosahedral particles. Generally, Begomovirus have either monopartite DNA-A or DNA-B (Concatomeric 2.6 or $2.7 \mathrm{~kb}$ ) or bipartite (Concatomeric $5.2 \mathrm{~kb}$ ) circular ssDNA genome.
The DNA-A genome has five open reading frames (ORFs), encoding for functional proteins i.e., AV1 coat protein $(\mathrm{CP}), \mathrm{AC} 1$ viral replication initiation protein (Rep), AC2-Transcriptional activator (Trap), AC3-replication enhancer (Ren), and AC4. The genome also has two ORFs in DNA-B encoding i.e., movement or mobility protein (MP) and a nuclear shuttle protein (NSP) ${ }^{2}$. The predominant geminiviruses are causative entities in leguminous species including greengram, black gram, french gram, pigeon pea, and soybean ${ }^{3}$. MYM virus is transmitted by whitefly, Bemisia 
tabaci Genn. (Hemiptera: Aleyrodidae). It is a polyphagous insect, completes its life cycle in less than 2 weeks to more than 10 weeks depending on temperature and host plant where it has greater ability to transmit disease ${ }^{4}$.

Geminiviruses are circular single-stranded (ss) DNA plant pathogens that can replicate double- stranded (ds) DNA via rolling circle mode of amplification (RCA) in host plants 5 . RCA is a process in which a circular DNA or RNA molecule is replicated in one direction through strand displacement activity of Ö29 DNA polymerase. First DNA molecule is displaced by newly synthesized DNA and releases the singlestranded DNA (ssDNA). The primer enzymatic extension combined with strand displacement generates a long ssDNA complementary to the DNA template. RCA is recognized as an important diagnostic tool to amplify the complete genome of viruses artificially under in vitro conditions. This technique is used to detect many ss, ds DNA viruses infecting different crops $^{6}$. The double stranded circular papilloma viral genome sample of infected leaf tissue was efficiently amplified using Ö29 DNA polymerase via RCA technique ${ }^{7}$, ${ }^{8}$. Similarly, Inoue-Nagata et al. ${ }^{9}$ used cloning of single circular DNA method in tomato for Tomato Chlorotic Mottle Virus.

The whiteflies act as natural vectors carrying viruses that spread viral diseases ${ }^{10}$. The host phloem cells are used by virus to enter and their viral aggregates pass on through it. The symptoms appear within two days as a scattered yellow spot on the young leaves turning to mosaic appearance, infected plant pods size decreases, leaf yellowing decreasing the efficiency of photosynthesis and causing a severe crop losses ${ }^{11}$. The insect would not persist in all seasons; hence, researchers are encountering issues with screening germplasm and assessing resistant varieties. In vitro cloning of the complete viral genomes through RCA is possible to develop screening techniques like Agro-inoculation, Agroinfiltration. Cloning a viral genome in a suitable vector is the possible solution for screening and challenging the testing material in the laboratory without any climatic barrier and escaping the transfer of viral components.

Viral transmission studies help in understanding inplanta gene - gene interaction, gene expression and functional analysis. Further, the Agroinoculation of viral genome into plants would be useful for understanding viral replication, assembly and their movement. Similar technique was followed using soyabean isolate to infect in greengram and blackgram ${ }^{12}$. In another study the tobacco leaves were infiltrated with Agro-clone for multiplication and propagation of Potato virus $X$ $(\mathrm{PVX})^{13}$. Madhuitha et $\mathrm{al}^{14}$ has evaluated Vigna germplasm was to detect the level of resistance/ susceptibility against yellow mosaic virus.

Agroinoculation and Agroinfiltration methods were first applied for the of both viral DNA/RNA genomes such as Cauliflower Mosaic Virus (CaMV) in turnip plant Maize Streak Virus (MSV) in maize ${ }^{15,16}$. Vaghchhipawala et al. ${ }^{17}$ reported that by using virus-induced gene silencing (VIGS) method to study plant-virus interactions, functional analysis of viral genomes and also for genetic screening with forward and reverse approaches. These techniques are applicable to investigate transient gene expression effects, analyze its protein localization and proteinprotein interactions in plant-pathogen studies. Agroinfiltration method was used for delivering viral vectors carrying Tobacco Mosaic Virus (TMV) and Potato Virus X (PVX) in leaf part or whole plant for gene expression studies ${ }^{17}$. Through Agroinfiltration method, sGFP tagged viruses of Tomato Torrado virus was inoculated in tomato and tobacco for studying molecular determinants during viral movement for analyzing plant-virus interactions. ${ }^{18}$ A cDNA clone of tomato mottle moasic virus (ToMMV) was used for agroinfiltration of tomato leaves, where pathogenicity and virus host interactions were studied through electron micrographs ${ }^{19}$.

In present study, we report a simple procedure for construction of agro-infectious genomic clones of MYMV. The complete genome of MYMV was amplified using Ö 29 DNA polymerase and digested genome was cloned in pCAMBIA2301 plant expression vector. This vector was used for Agroinfiltration and Agroinoculation studies in greengram. The yellow mosaic symptoms in infected samples were assessed and screened through PCR using genes specific markers encoding DNA-A and DNA-B in plants. . 


\section{MATERIALS AND METHODS}

\section{Extraction of genomic DNA from infected leaves of greengram}

The greengram plants exhibiting mosaic symptoms with irregular green and yellow spots were collected from greengram fields in Acharya N. G. Ranga Agricultural University, LAM farm, AP, India (Fig 1A). Genomic DNA was extracted from infected leaf samples and control plants by following CTAB method. Briefly, infected leaves were ground with CTAB buffer $(10 \mathrm{mM}$ EDTA, $100 \mathrm{mM}$ Tris, $1.4-2.0 \mathrm{M} \mathrm{NaCl}, 2 \%$ CTAB, $2-5 \%$ $B$-mercaptoethanol). The leaf slurry incubation was done at $60^{\circ} \mathrm{C}$ for $30 \mathrm{~min}$, equal volumes of Phenol: Chloroform : Iso-amylalcohol (25: 24: 1) was added to the samples supernatant and centrifuged for $10 \mathrm{~min}$ at 13,000 rpm. The supernatant was then added with Chloroform: Iso-amylalcohol (24: 1) followed by centrifugation. Further the supernatant was precipitated with the addition of $100 \%$ isopropanol and $7.5 \mathrm{M}$ Sodium acetate. Finally, the pellet was washed with $70 \%$ ethanol and DNA pellet was dissolved in sterile water ${ }^{20}$. The extracted DNA was qualitatively measured by resolving in $0.8 \%$ agarose gel, then purity was analyzed at OD of 260 and $280 \mathrm{~nm}$ by NanoVue spectrophotometer (GE healthcare, USA).

Rolling circle amplification of MYMV genome

The genomic DNA from infected and control samples was subjected to RCA using Ö 29 DNA polymerase (Thermo Scientifics, USA) according to the instructions given by manufacturer. Briefly, reaction mixture was prepared by the addition of $100 \mathrm{ng}$ of RCA DNA, $500 \mu \mathrm{M}$ Exo-Resistance Random primer and adjusting reaction volume for $10 \mu \mathrm{l}$ with water. Following with incubation of the reaction mixture was done at $5 \mathrm{~min}$ at $95^{\circ} \mathrm{C}$ and chilled on ice for $2 \mathrm{~min}$. To this reaction mixture, $10 \mathrm{mM}$ dNTPs and $1 \mu \mathrm{l}$ Ö29 DNA polymerase $(10 \mathrm{U} / \mu \mathrm{l})$ and Pyrophosphate inorganic $(0.1 \mathrm{U} / \mu \mathrm{l})$ was added and the final volume was made up to $15 \mu \mathrm{l}-20 \mu \mathrm{l}$ based on DNA concentration. The above mixture was then incubated at $30^{\circ} \mathrm{C}$ for $18 \mathrm{hrs}$ and the reaction was terminated by keeping at $65^{\circ} \mathrm{C}$ for $10 \mathrm{~min}$.

Confirmation of presence of DNA-A and DNA-B components in MYMV genome

To confirm whether the RCA possessing, DNA-A and B, was processed using gene specific primer sets such as $A C 1, V C P 2$ ( $A V 1), B C 1$ and $B V 1$ through PCR. The reaction performed in 10 il containing $10 \times$ PCR reaction buffer, $2.5 \mathrm{mM}$ dNTPs, $2.5 \mathrm{mM} \mathrm{MgCl}_{2}$, each primer 10 pmols, $2.5 \mathrm{U} / \mathrm{il}$ Taq DNA polymerase (Takara) and $100 \mathrm{ng}$ RCA-DNA. The primer details are given in (Table 1). The PCR program was followed as $94^{\circ} \mathrm{C}$ for 5 min for initial denaturation; $94{ }^{\circ} \mathrm{C}$ for $40 \mathrm{~s} ; 54{ }^{\circ} \mathrm{C}$ for 40s for annealing of $A C 1, V C P 2$ (AV1), $B C 1$ and $B V 1$, extension at $72^{\circ} \mathrm{C}$ for $40 \mathrm{~s}$ and $72^{\circ} \mathrm{C}$ for 7 $\min$ for final extension. After the amplification, the PCR products were resolved on $1 \%$ agarose gel in $1 \mathrm{x}$ TAE buffer at $100 \mathrm{v}$ through electrophoresis. The gel was analyzed with gel documentation system (Syngene, USA).

Construction of pCAMBIA2301 vector with MYMV genome RCA product

RCA products were digested with Bam HI and Hind III by following manufacturer's instructions (Thermo Scientific, USA). RCA products were digested individually with Bam HI and Hind III using about $2 \mu \mathrm{g}$ of RCA product, $10 \mu \mathrm{l}$ buffer, $10 \mathrm{U} / \mu \mathrm{l}$ of Bam HI and Hind III restriction enzyme, adjusting reaction volume with water to $50-100 \mu \mathrm{l}$, incubated for $25 \mathrm{~min}$ at $37^{\circ} \mathrm{C}$ and were inactivated by an enzyme at $85^{\circ} \mathrm{C}$ for $10 \mathrm{~min}$. Further, $0.8 \%$ Agarose gel was used to resolve the digested products. The digested DNA fragments were excised from the gel was eluted with Qiagen Gel Extraction kit (Qiagen, USA). The eluted DNA fragments (300 ng) were ligated with pCAMBIA2301 using $\mathrm{T}_{4}$ ligase (Thermo scientific, USA) individually (Fig 1B).

\section{E. coli and Agrobacterium transformation}

The ligated products that contain pCAMBIA2301 vector and MYMV genome (2.6 $\mathrm{kb}$ and $2.7 \mathrm{~kb}$ ) fragments separately was transferred into $E$. coli (DH5á) by heat shock method ${ }^{21}$. About $10 \mu 1$ ligated product was added into competent DH5á cells. The mixture was incubated on ice for $5 \mathrm{~min}$, and given heat shock at $42^{\circ} \mathrm{C}$ for $90 \mathrm{~s}$ and incubated on ice for $1 \mathrm{~min}$. To the mixture, $1 \mathrm{ml}$ of LB broth was added and incubated for $1 \mathrm{hr}$ at $37^{\circ} \mathrm{C}$, $180 \mathrm{rpm}$ in the incubator. After the incubation, $50 \mu \mathrm{l}$ cell suspension was spread onto LB agar medium supplemented with kanamycin $(50 \mathrm{mg} / \mathrm{L})$ and incubated at $37^{\circ} \mathrm{C}$ for overnight (Fig $2 \mathrm{~A}$ ). Then the colony PCR was performed for detecting the cloned fragments such as DNA-A i.e., AC1, AV1 (VCP2), and DNA-B i.e., $\mathrm{BC} 1, \mathrm{BV} 1$ using gene 
specific primers. Plasmid DNA was isolated from positive colonies using Qiagen Plasmid isolation kit (Qiagen, USA). The sequencing of amplified fragments was done at DNA sequencing facility (Eurofins Genomics India Pvt, Ltd, Bangalore). Analysis of sequenced data of MYMV DNA was carried out by multiple sequence alignment.

The two plasmids DNA-A and DNA-B were then transferred separately into Agrobacterium through freeze thaw method. About $1 \mu \mathrm{g}$ of plasmid DNA was added into $200 \mu \mathrm{l}$ of Agrobacterium LBA4404 cells, and snap freezed in liquid nitrogen, $1 \mathrm{ml}$ of LB broth was and incubated at $28^{\circ} \mathrm{C}$ for $4 \mathrm{hr}$. The suspension was then plated on LB agar plates supplemented with streptomycin $(50 \mathrm{mg} / \mathrm{L})$ kanamycin $(50 \mathrm{mg} / \mathrm{L})$, and rifamycin $(20 \mathrm{mg} / \mathrm{L})$ followed by incubation at $28^{\circ} \mathrm{C}$ for $48-72 \mathrm{hr}$. Plasmid DNA was isolated from positive colonies using Qiagen Plasmid isolation kit (Qiagen, USA) and glycerol stocks were prepared and used for Agrobacterium transmissions.

\section{Viral transmission studies in green gram Rubbing}

Mechanical transmission of MYM in greengram was performed using rubbing method. The sap was prepared from MYMV infected leaves of greengram by macerating in the cold sodium phosphate buffer $(300 \mathrm{mg}$ of powdered tissue with $1.5 \mathrm{ml}$ of sodium phosphate buffer) and centrifuged at $4{ }^{\circ} \mathrm{C}$ at 13,000 for $5 \mathrm{~min}$. About $100 \mu \mathrm{l}$ of supernatant was rubbed on the adaxial surface of 3-4 fully expanded leaves per plant. Symptoms were scored after 2 days of rubbing. The genomic DNA was extracted from infected leaves and analyzed through the PCR using AC1 gene specific primers.

\section{Agro-infiltration}

Agrobacterium containing pCAMBIA2301 vector harbouring DNA-A and DNA-B was grown till the $\mathrm{OD}_{600}$ reaches $0.4-0.6$ at $28^{\circ} \mathrm{C}$ for $48 \mathrm{hrs}$. Then, the cultures was centrifuged at 5,000 rpm and each culture was diluted in three volumes of Agro-infiltration medium $(10 \mathrm{mM}$ $\mathrm{MgCl}_{2,} 10 \mathrm{mM}$ MES, $\mathrm{pH}$ 5.6) until culture $\mathrm{OD}_{600}$ reached to 0.5 . Further, culture was incubated at room temperature with gentle shaking for 1-2 hrs. Both cultures were mixed together along with 100 $\mu \mathrm{M}$ acetosyringone and incubated for $2 \mathrm{hrs}$ for vir gene induction ${ }^{13}$. Culture was infiltrated on abaxial surface of leave without any needle to infiltrate leaves of 4 to 5-week-old plants of greengram. After post infection, occurrence of yellow mosaic symptoms (4 to 8 days), the genomic DNA was extracted from infected leaves and analyzed through the PCR using $\mathrm{AC} 1$ gene specific primers (Figure 3).

\section{Agro-inoculation}

The greengram seeds were surface sterilized with $70 \%$ ethanol and imbibed in water for overnight. The seeds were pricked with fine syringe and inoculated with medium along with $100 \mu \mathrm{M}$ acetosyringone and seeds were maintained at $28^{\circ} \mathrm{C}$ for $3 \mathrm{hrs}$ and excess culture was removed and seeds were sown in soil. Post 1521-days of infection, the MYMV symptoms were phenotypically characterized and the symptoms were recorded in the trifoliate leaves. The uninoculated seeds of each line were maintained as control.

\section{RESULTS AND DISCUSSION}

\section{Detection and Confirmation of DNA-A and DNA-B components of MYMV genome}

Yellow mosaic disease (YMD) of green gram and black gram is economically very important and it is caused by two species of virus, MYMV and MYMIV and are transmitted by white flies. Incidence of this disease leads to cent percent yield loss of the crop. Hence it is necessary to develop the MYMV resistant varieties through Marker Assisted Breeding. To identify the new sources of resistant variety, we need to screen the germplasm against MYMV. Screening under the field conditions was always influenced by the different factors like i.e., environmental changes, whitefly genotypes etc.. Advancement in the molecular biology provides us three different method of screening methods: Rubbing method, Agroinfiltration and Agroinoculation (Aguilar et $\mathrm{al}^{13}$; Usharani et al. $2006^{23}$; Biswas and Varma ${ }^{24}$; Mandal et al. ${ }^{25}$ ). In the present study, we have followed these three techniques for greengram screening against YMD. Greengram plants with typical characteristics of mosaic symptoms including green and yellow patches (Fig 1A) with lesser flowers and pods in the fields were chosen for this experiment. The infected and control leaf samples were collected for DNA extraction. About $20 \mu \mathrm{g}$ of DNA was extracted from those 
infected leaves. The DNA contains both plant and viral genomic DNA. The purity of the DNA was analyzed by NanoVue at OD 260/280 with 1.8 . The complete genome of MYMV was amplified from $200 \mathrm{ng}$ of genomic DNA as a template by using Ö29 DNA polymerase (Fig 1B). In this method, the DNA fragments amplifies as mini circles through rolling circle amplification by random priming for generating high concentration of concatermerized DNA Dean et al. ${ }^{22}$. Then the RCA product was partially digested with $\mathrm{Bam} \mathrm{HI}$ and Hind III, obtained a fragments with a size of $2.6 \mathrm{~kb}$ and $2.7 \mathrm{~kb}$ each. The digested product was confirmed by amplifying coat protein by using gene specific primers and obtained $0.7 \mathrm{~kb}$ fragment (Fig 1C). Similar to our work, Kumar et al. ${ }^{26}$ reported $2.6 \mathrm{~kb}$ and $2.7 \mathrm{~kb}$ fragments of DNA A and DNA $B$ isolated from cowpea against MYMV. Similarly, in the other report Jyothsna et al ${ }^{27}$ reported 2.7 $\mathrm{kb}$ and $2.6 \mathrm{~kb}$ of viral genomes isolated from Rhynchosia minima weed. ${ }^{28}$ In contrast, Haq et al. ${ }^{28}$ reported $2 \mathrm{~kb}$ and $1.5 \mathrm{~kb}$ fragments of DNA-A and B from blackgram.. Based on the reports to avoid the confusion we have amplified the DNA-A and DNA-B with reported specific primers and sequenced.

RCA products cloning in pCAMBIA2301 expression vector and Agrobacterium transformation

Geminiviruses, damages many crop on several countries. To control the spread of the virus demands efficient diagnostic tools like specific antibodies, PCR and RFLP (Briddon and Markham $^{29}$ ). Later Dean et al. ${ }^{22}$ provided the feasible procedure by the uses of Bacillus subtilis bacteriophage Phi29 polymerase. By using this DNA polymerase we can able to do polymerase and stand displacement activity through RCA mechanism. Through this RCA approach we can detect and characterize geminiviruses and related subgenomic components (Haible et al. ${ }^{1}$ ). In the present study, we have used the RCA mechanism to characterize YMD in greengram. The digested DNA fragment was cloned in the Bam HI site of pCAMBIA2301 using $\mathrm{T}_{4}$ DNA ligase and another DNA fragment was cloned in the Hind III site of pCAMBIA2301 using $T_{4}$ DNA ligase. Then, two plasmids were transferred into Agrobacterium for further viral transmission studies. The Agro colonies appeared in $48 \mathrm{hr}$ of incubation (Fig 2A). 
The colonies were confirmed by PCR. using a different set of primers including $\mathrm{AC} 1$ (replication protein), $\mathrm{BC} 1$ (mobility protein) and BV1 (shuttle protein), which showed expected amplification products of $0.7 \mathrm{~kb}, 0.8 \mathrm{~kb}$ and $0.7 \mathrm{~kb}$ respectively (Fig 2B and 2C). All these fragments were sequenced by Eurofins Genomics, Bangalore. About $97 \%$ of DNA-A sequence was matched with accession no DQ400847.1 isolated from blackgram. This sequence also matches $96-97 \%$ with the DNA-A of another crop like soyabean, French Bean, greengram infected with YMD. In case of DNA-B the sequences matched $97 \%$ with the accession no AJ439059.1. reported from mungbean. DNA-B sequences matched only with mungbean not with any other crops . Based on the blast and Clustal w analysis, we confirmed our isolated clone belongs to YMD DNA-A and DNA-B and used for agrotransformation. . The confirmed Agrobacterium LBA4404 clone with MYMV genome was used for further virus transmission studies.

\section{Mechanical transmission with MYMV maintained Agrobacterium clones}

Transmission may be due to rubbing of plants with liberated virus from damaged hair cells or epidermal cells ${ }^{30}$. The virus is transmitted by rubbing the viral sap on to the adaxial side of trifoliate leaves of greengram (Fig 3A). The greengram is highly susceptible to MYMV. The severe yellow mosaic symptoms appeared on greengram leaves in 7-10 days post infection (Fig 3B). Further, the infected and control plant were used for detecting viral particle accumulation in the plants through PCR. The PCR results indicated that the $\mathrm{AC} 1$ fragment with $0.7 \mathrm{~kb}$ was amplified in all infected samples. However, uninfected control did not showed any symptoms and failed to show amplification with AC1 primers(Fig 3C). . About $90 \pm 1 \%$ of 10 leaflets rubbed with sap

Table 2. PCR screening based on appearance of symptoms in blackgram and greengram after challenging with MYMV through Agro inoculation

\begin{tabular}{lccccc}
\hline Variety & $\begin{array}{c}\text { No of } \\
\text { seedling } \\
\text { inoculated }\end{array}$ & $\begin{array}{c}\text { No of } \\
\text { seedling } \\
\text { germinated }\end{array}$ & $\begin{array}{c}\text { No of plants } \\
\text { showed YMD } \\
\text { symptoms }\end{array}$ & $\begin{array}{c}\text { No of plants } \\
\text { showed AC1 } \\
\text { amplification }\end{array}$ & $\begin{array}{c}\text { Percentage of } \\
\text { plants observed } \\
\text { with symptoms }\end{array}$ \\
\hline LGG460 (Gg-S) & 15 & 10 & 9 & 10 & $90 \%$ \\
GG150(Gg-R) & 15 & 14 & 1 & 1 & $7.1 \%$ \\
LBG685(Bg-S) & 15 & 13 & 11 & 11 & $84.6 \%$ \\
PU31(Bg-R) & 15 & 15 & 1 & 1 & $6.6 \%$ \\
\hline
\end{tabular}
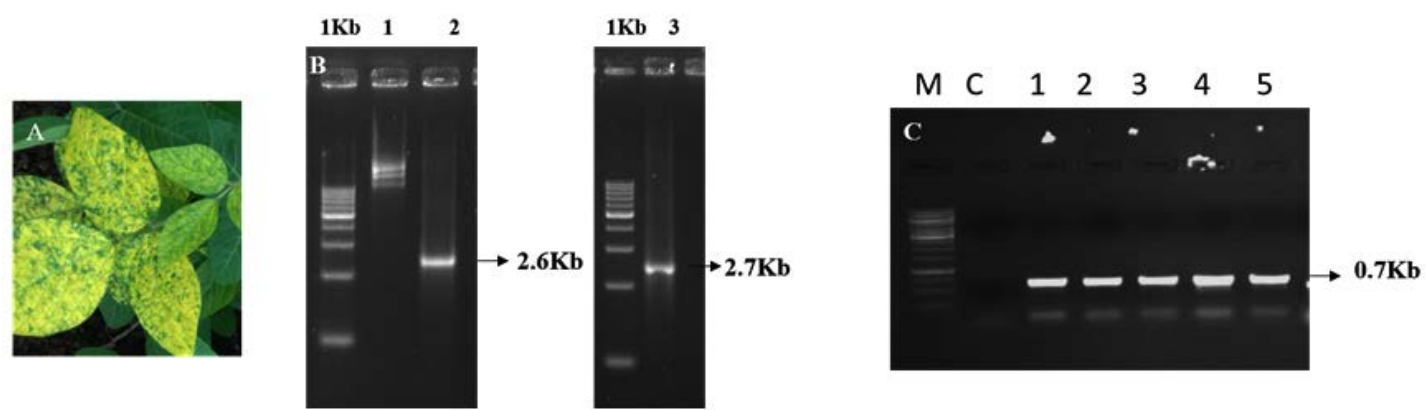

A. Greengram showing typical yellow mosaic symptoms collected and isolated genomic DNA. B. Rolling circle mediated amplification of complete viral genomic DNA using Ö 29 DNA polymerase (1), Restriction and digestion of viral genome by Bam HI (2.6 kb) and (3) Restriction and digestion of viral genome by Hind III ( $2.7 \mathrm{~kb}) \mathrm{C}$. RCA product confirmation of viral genome using Coat protein primers. $1 \mathrm{~kb}$ : ladder, C: Uninfected leaf sample, 1 to 5: infected samples of greengram.

Fig. 1. Cloning of MYM viral genome using Ö 29 DNA polymerase 
extracted from MYMV infected greengram plants in triplicates, developed yellow mosaic symptoms after 5 days of post infection. During this period, it allowed the virus particles penetrate the leaf surface. Aguilar et al. ${ }^{13}$ reported that the mechanical rubbing of PVX sap inoculum on the surface of
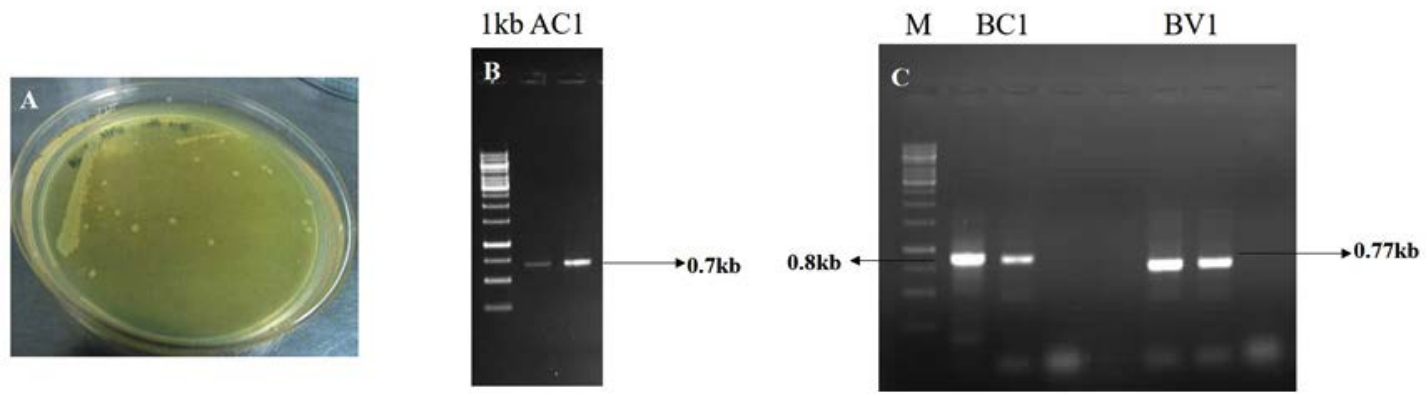

A. The digested samples were cloned into plant expression pCAMBIA2301 vector and transferred into DH5á cells and then into Agrobacterium through electroporation. B. Agarose gel picture showing confirmation of MYMV DNA-A using AC1 representing $0.7 \mathrm{~kb}$ fragment and C. DNA-B confirmation with $\mathrm{BC} 1$ and $\mathrm{BV} 1$ specific primers showing $0.89 \mathrm{~kb}$ and $0.77 \mathrm{~kb}$ fragments respectively. $1 \mathrm{~kb}$ : ladder

Fig. 2. Cloning of MYM viral genome into pCambia2301 and confirmation of viral genes using gene specific primers:
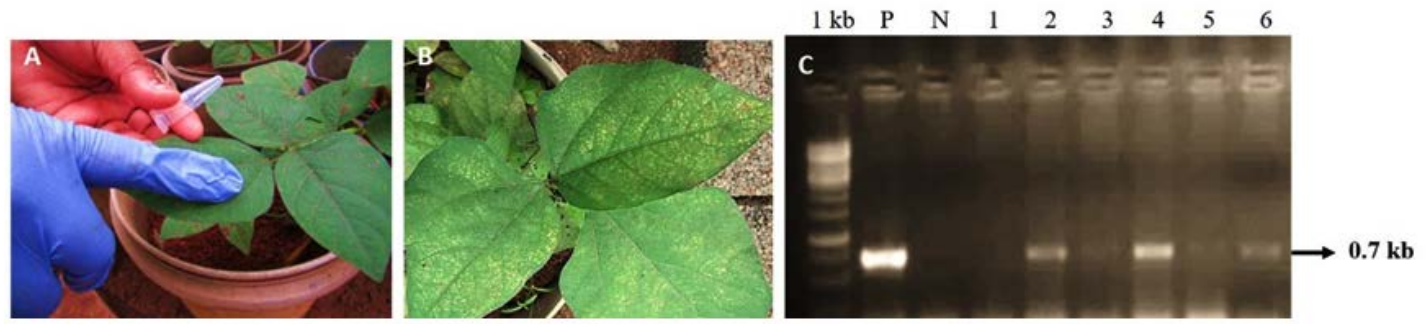

A. Viral inoculum prepared from infected leaf samples and ruptured on adaxial side of greengram. B. Agrobacterium culture harboring MYMV clone infiltration using syringe. The mosaic symptoms were appeared in 7 dpi. C. The gel picture showing the amplification of $\mathrm{AC} 1$ representing $0.7 \mathrm{~kb}$ fragment. $1 \mathrm{~kb}$ : ladder, P: positive control, $\mathrm{N}$, negative control; 1 to 6 ; test samples

Fig. 3. Viral transmission studies using mechanical rubbing
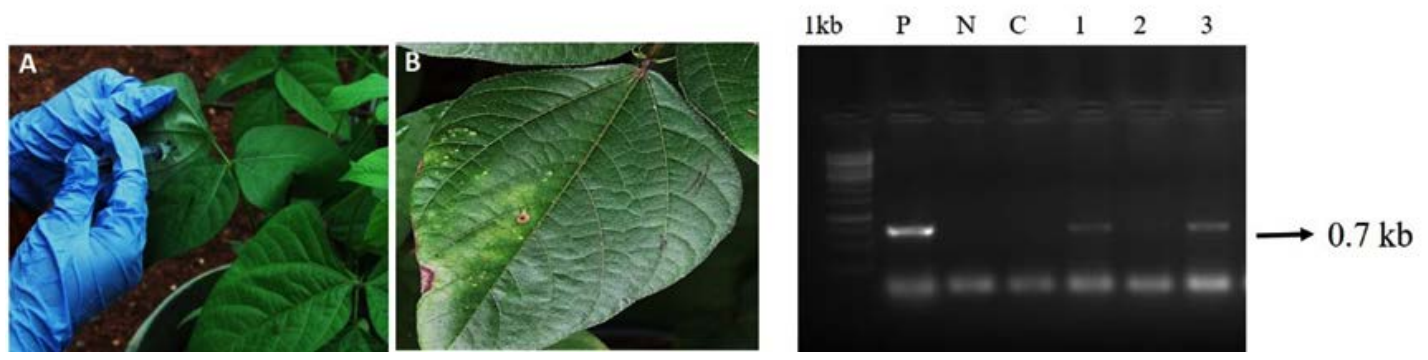

A. 45 day old leaf samples were infiltrated with syringe containing Agrobacterium culture. B. Appearance of mosaic symptoms at infiltrated region in $5 \mathrm{dpi}$. C. Agarose gel picture showing the PCR amplified products with expected amplification of AC1 gene with $0.7 \mathrm{~kb}$.

Fig. 4. Agro infiltration using MYMV clone. 
Nicotiana benthamiana allowed penetration and propagation of viral particles and the symptoms appeared in 7 days of post infection. Similarly, rubbing method was reported for transmission of sugarbeet virus in Beta vulgaris and Spinacia oleracea crops (Kassanis ${ }^{31}$ ). Another Begomovirus, Curly top virus which affects the different crops i.e., tomatoes, beans, cassava, squash and cotton also transmitted by rubbing method (Saad et al..$^{32}$ ). Singh and Awasthi ${ }^{33}$ reported different artificial mechanical transmission of virus like TMV, CMV, TSV, Okra mosaic virus, Papaya ringspot virus, Cowpea mosaic virus and alfalfa mosaic virus in tobacco, tomato, sunflower, okra, papaya, cowpea and potato (Sacrista'n et al..$^{34}$; Jalender et $a .^{35}$; Sundaresha et al..$^{36}$; Givord and Hirth ${ }^{37}$; Gonsalves ${ }^{38}$; Surekha et al. ${ }^{39}$; El-Abhar et al. ${ }^{40}$ ).

\section{Agroinfiltration using MYMV Agrobacterium clone}

Agro culture was infiltrated on the abaxial side of the trifoliate stage of greengram. The severe yellow mosaic symptoms were observed in 21 days of post infection (dpi) in greengram leaves. None of the symptoms observed in control leaves. The viral DNA was detected in in Agroinfiltrated leaves using $\mathrm{AC} 1$ gene specific primers. The expected amplicon size of $0.7 \mathrm{~kb}$ was obtained in two out of three symptomatic plants (Fig 4C). However, the uninfected control plants didn't show any amplification. Zhang et al. ${ }^{41}$ constructed cDNA clone of Wheat yellow mosaic virus (WYMV) genomic RNA and used Agroinfiltrated for viral multiplication and systemic infection in tobacco
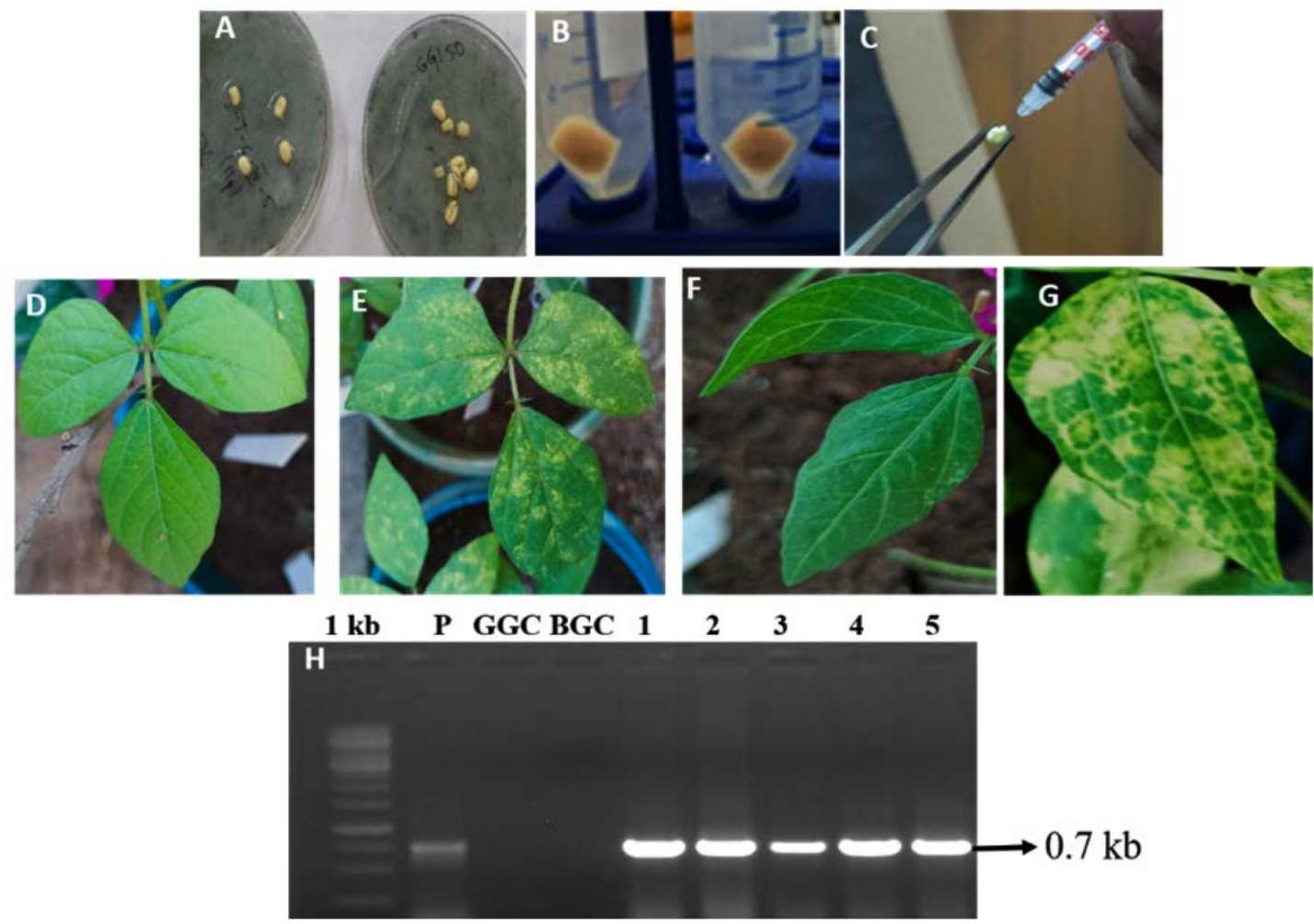

A. overnight soaked greengram (LGG460) and black gram (LBG685) seeds B. Agrobacterium pellet after centrifugation C. Pricking of seedling for effective infection with Agrobacterium. D. Control leaves of greengram E. Spread and appearance of mosaic symptoms on 5 dpi leaves of greengram F. control leaves of blackgram G. typical yellow mosaic symptoms on 21 dpi leaves of blackgram H. Agarose gel picture showing the amplification of $\mathrm{AC} 1$ gene which accumulated in virus infected greengram (1 to 3 lanes) and blackgram (4 \& 5) representing 0.7 $\mathrm{kb}$ fragment. $1 \mathrm{~kb}$ : ladder, GGC: Greengram control, BGC: Blackgram control.

Fig. 5. Viral transmission studies through Agroinoculation on greengram and blackgram. 
and wheat. Interestingly synergic effect was detected between WMYV and Chinese wheat mosaic virus (CWMV).

Liu et al ${ }^{42}$ reported that through agroinfiltration tobacco rattle virus (TRV) was transmitted in tomato and studies the functional analysis in detail (Liu et al., ${ }^{42,43,44}$; Dong et al., ${ }^{45}$; and Anand et al., ${ }^{46}$ ). In another study, Gao et al., ${ }^{47}$ reported that agroinfiltration studies had typical mosaic symptoms in J.curcas with Jatropha curcas mosaic disease and used for screening the cultivars to identify the virus resistant plants. Wieczorek et al., ${ }^{48}$ developed a construct of infectious cones of tomato torrado virus and transmitted to plants through agroinfiltration.. Similarly, Usharani et al., ${ }^{49}$ studied AV promoter expression via., infiltration in tobacco and different legumes by a reporter gene i.e., GUS.

Transmission of MYMV using Agro-inoculation technique

Agroinoculated plants were assessed for yellow mosaic symptoms in Greengram and Blackgram. For this experiment, LGG460 (greengram) and LBG685 (blackgram) lines were subjected to Agro-inoculation in five replications. Severe yellow mosaic symptoms were observed in 14 days after inoculation in trifoliate leaves of blackgram and greengram (Fig 5D and 5F), however, no symptoms were developed in the control uninoculated plants. The genomic DNA was extracted from the leaves showing yellow mosaic symptoms. The PCR confirmation was done for the viral DNA presence i.e., MYMV AC1 gene and all inoculated samples showed expected amplification of $0.7 \mathrm{~kb}$ fragment (Fig 5H). MYMV symptoms were appeared $90 \%$ of greengram and $84.6 \%$ in blackgram plants inoculated with Agro infectious clone. However, the resistant lines in greengram and blackgram have shown minimal symptoms (Table 2). Jacob et al ${ }^{50}$ reported MYMV which infects blackgram, mungbean and soyabean. Usharani et al. ${ }^{12}$ demonstrated viral DNA presence in symptomatic plants agro-inoculate. Asymptomatic of resistant genotypes compared to control plants of were compared with controls through PCR.Advantage of agroinoculation is to observe the uniform symptoms in all infected leaves, which would make easier to compare with control plants ${ }^{24}$. MYMV symptoms are analysed based on the scattered appearance of yellow-color spots on young leaves which turns into mosaic pattern $^{11}$. Sudha et al. ${ }^{51}$ screened germplasms of mungbean to identify the resistant/susceptible against MYMV and analysed its viral load by PCR with coat protein gene primers.

Agroinoculation studies were used to screen Tomato yellow leaf curl virus in Sweet pepper, and Pepper yellow leaf curl virus in capsicum (Kil et al., ${ }^{52}$; Koeda et al., ${ }^{53}$ ). In another study, Overcoming a resistance against Tomato yellow leaf curl virus in Lycopersicon species was observed by Kheyr et al. ${ }^{54}$.

\section{CONCLUSION}

The MYMV genome was amplified using Ö29 DNA polymerase from infected samples of greengram. The cloned MYMV construct is very useful in bioassay experiments for screening different genotypes of greengram, blackgram and other crops. These viral transmission tools would be employed for screening the CRISPR mediated yellow mosaic virus resistance in pulse crops.

\section{ACKNOWLEDGEMENTS}

We sincerely acknowledge the funding support of Council of Scientific and Industrial Research (CSIR) with No. 38(1450)/18/EMR II. We thank Executive Director and Agri Biotech Foundation for encouragement and support

\section{Conflicts of interest}

The authors declare no conûicts of interest

\section{Funding Sources}

The grants funded by Council of Scientific and Industrial Research, INDIA under Extra Mural Research scheme to Dr. G. Mallikarjuna, Agri Biotech Foundation, Hyderabad, India. Ref no. 38(1450)/18/EMR II.

\section{REFERENCES}

1. Haible D., Kober S. and Jeske H. Rolling circle amplification revolutionizes diagnosis and genomics of geminiviruses. J .Virol. Methods. 2006; 135: 9-16

2. Rojas M.R., Hagen C., Lucas W.J. and Gilbertson R.L. Exploiting chinks in the plant's armor: evolution and emergence of geminiviruses. Annu. Rev. Phytopathol. 2005; 43: 361-394.

3. Fauquet C.M. and Stanley J. Geminivirus 
classification and nomenclature: progress and problems. Ann. Appl. Biol. 2003; 165-189.

4. Nariani T.K. Yellow mosaic of mung (Phaseolus aureus L.). Ind. Phytopathol. 1960; 13:24-29.

5. Jeske H. Geminiviruses. In: TT Viruses. 2009; 185-226.

6. Bhat A.I. and Rao G.P. Rolling Circle Amplification (RCA), In Characterization of Plant Viruses- Methods and Protocols (Humana, New York: Springer). 2020; 377-382.

7. Rector A., Tachezy R., Van Doorslaer K., MacNamara T., Burk R.D., Sundberg J.P. and Van Ranst $M$. Isolation and cloning of a papillomavirus from a North American porcupine by using multiply primed rollingcircle amplification: the Erethizon dorsatum papillomavirus type 1. Virology, 2005; 331: 449-456.

8. Stevens H., Rector A. and Van Ranst M. Multiply primed rolling-circle amplification method for the amplification of circular DNA viruses. Cold. Spring. Harb. Protoc. 2010; pdb.prot5415.

9. Inoue-Nagata A.K., Albuquerque L.C., Rocha W.B. and Nagata T. A simple method for cloning the complete begomovirus genome using the bacteriophage ö29 DNA polymerase. J. Virol. Methods. 2004; 209-211.

10. Selvi R., Muthiah A.R., Manivannan N., Raveendran T.S., Manickam A. and Samiyappan, R. Tagging of RAPD marker for MYMV resistance in mungbean (Vigna radiata (L.) Wilczek). Asian. J. Plant Sci. 2006; 277-280.

11. Malathi V.G. and John P. Mungbean yellow mosaic viruses. Desk encyclopedia of plant and fungal virology. Acad. Press, London. 2009; 217-226.

12. Usharani, K.S., Surendranath, B., Haq, Q.M. and Malathi, V.G., 2005. Infectivity analysis of a soybean isolate of Mungbean yellow mosaic India virus by agroinoculation. J. Gen. Plant. Pathol.2005; 230-237.

13. Aguilar E., del Toro F.J., Chung B.N., Canto T. and Tenllado F.,. Infection of Nicotiana benthamiana Plants with Potato Virus X (PVX). Bio-Protoc. 2016; 6: e2063

14. Madhumitha B., Karthikeyan A., Mathivathana M.K., Aiyanathan K.E.A. and Sudha M. Evaluation of Vigna germplasms for resistance to mungbean yellow mosaic virus using agro inoculation. Electronic. J. Plant. Breeding. 2019; 692-698.

15. Grimsley N., Hohn B., Hohn T. and Walden R. "Agroinfection," an alternative route for viral infection of plants by using the Ti plasmid. Proc. Natl. Acad. Sci. 1986; 3282-3286.

16. Grimsley N., Hohn T., Davies J.W. and Hohn B.
Agrobacterium-mediated delivery of infectious maize streak virus into maize plants. Nature. 1987; 177-179.

17. Vaghchhipawala Z., Rojas C.M., Senthil-Kumar M. and Mysore K.S. Agroinoculation and agroinfiltration: simple tools for complex gene function analyses. In: Pereira, A. (Ed.), Plant Reverse Genetics. Humana Press, 2011; 65-76.

18. Wieczorek P., Budziszewska M., Fr ${ }^{1}$ ckowiak P. and Obrêpalska-Stêplowska A., 2020. Development of a New Tomato Torrado VirusBased Vector Tagged with GFP for Monitoring Virus Movement in Plants. Viruses 2020; 1195.

19. Tu L., Wu S., Gao D., Liu Y., Zhu Y. and Ji Y. Synthesis and Characterization of a Full-Length Infectious cDNA Clone of Tomato Mottle Mosaic Virus. Viruses. 2021; 1050.

20. Prema G.U. and Rangaswamy K.T. Molecular detection and characterization of coat protein gene of Mungbean Yellow Mosaic Virus (MYMV) from Karnataka. Int. J. Agril. Sci. 2018; 5118-5122.

21. Sambrook J. and Russel D.W. Extraction and purification of plasmid; screening of bacterial colonies by hybridization. Molecular Cloning: a laboratory manual, 3rd Ed. Cold Spring Harbor Laboratory Press, Cold Spring Harbor, New York, USA. 2001

22. Dean F.B., Nelson J.R., Giesler T.L. and Lasken R.S. Rapid amplification of plasmid and phage DNA using phi29 DNA polymerase and multiplyprimed rolling circle amplification. Genome. Res, 2001; 1095-1099.

23. Usharani K.S., Periasamy, M and Malathi V.G. Studies on the activity of a bidirectional promoter of Mungbean yellow mosaic India virus by agroinfiltration. Virus research, 2006; 154-162.

24. Biswas K.K and Varma A. Evaluation of resistance in blackgram (Phaseolus mungo) to variants of mungbean yellow mosaic geminivirus. Indian J. Agril. Sci. 2001; 215-218.

25. Mandal B., Varma A. and Malathi V.G. Systemic infection of Vigna mungo using the cloned DNAs of the blackgram isolate of mungbean yellow mosaic geminivirus through agroinoculation and transmission of the progeny virus by whiteflies. J. Phytopathology. 1997. 145; 505-510.

26. Kumar S., Tanti B., Mukherjee S.K and Sahoo L. Molecular characterization and infectivity of Mungbean Yellow Mosaic India virus associated with yellow mosaic disease of cowpea and mungbean. Biocat Agri Biotech, 11: 183-191.

27. Jyothsna P., Rawat R and Malathi V.G. Molecular characterization of a new begomovirus infecting a leguminous weed Rhynchosia minima in India. Virus Genes, 2011; 407-414. 
28. Haq Q.M.I., Rouhibakhsh A., Ali A and Malathi V.G. Infectivity analysis of a blackgram isolate of Mungbean yellow mosaic virus and genetic assortment with MYMIV in selective hosts. Virus Genes, 2011; 429-439.

29. Briddon R.W and Markham P.G. Use of PCR in the detection and characterization of geminiviruses. Bull. OEPP, 1995; 315-320.

30. Biswas K.K., Tarafdar A. and Biswas K. Viral diseases and its mixed infection in mungbean and urdbean: major biotic constraints in production of food pulses in India. Modern Trends in Microbial Biodiversity of Natural Ecosystem. 2012; 301317.

31. Kassanis B., The transmission of sugar beet yellows virus by mechanical inoculation. Annals of Applied Biology, 1949; 270-272.

32. Saad M.F.M., Sau A.R., Akbar M.A., Baharum S.N., Ramzi A.B., Talip N and Bunawan H. Construction of Infectious Clones of Begomoviruses: Strategies, Techniques and Applications. Biology, 2021; 604.

33. Singh S., Nirmalkar V.K and Awasthi L.P. Recent advances in begomovirus research in India. Applied Plant Virology. 2020; 493-513.

34. Sacristan S., Diaz M., Fraile A and García-Arenal F. Contact transmission of Tobacco mosaic virus: a quantitative analysis of parameters relevant for virus evolution. J. virology, 2011; 4974-4981.

35. Jalender P., Bhat B.N.,Anitha K and Vijayalakshmi $\mathrm{K}$. Studies on transmission of cucumber mosaic virus (CMV) by sap inoculation in tomato. Int. J. Pure and App. Biosci. 2017; 1908-1912.

36. Sundaresha S., Sreevathsa R., Balol G.B., Keshavareddy G., Rangaswamy K.T. and Udayakumar M. A simple, novel and high efficiency sap inoculation method to screen for tobacco streak virus. Physiol. Mol. Biol Plants. 2012; 365-369.

37. Givord L. and Hirth L. Identification, purification and some properties of a mosaic virus of okra (Hibiscus esculentus). Annals of Applied Biol. 1973; 359-370.

38. Gonsalves D. Control of papaya ringspot virus in papaya: a case study. Annual review of phytopathol. 1998; 415-437.

39. Surekha S., Magar S.J., Satyadev P and Prasanna K.V. Transmission Studies on an Indian Isolate of Cowpea Mosaic Virus. Int. J. Curr. Microbiol. App. Sci. 2018; 528-534.

40. M. El-Abhar M.A. El-Abhar M.A. Elkady K.M. Ghanem H.A. Bosila. Identification, characterization and ultrastructure aspects of Alfalfa mosaic virus infecting potato (Solanum tuberosum L.) in Egypt. J. Virol. Sci. 2018; 68-77.

41. Zhang F., Liu S., Zhang T., Ye Z., Han X., Zhong
K., Yang J., Chen J. and Liu P. Construction and biological characterization of an infectious fulllength cDNA clone of a Chinese isolate of Wheat yellow mosaic virus. Virology. 2021; 101-109.

42. Liu, Y., Schiff, M. and Dinesh Kumar, S.P., 2002. Virus induced gene silencing in tomato. The Plant Journal, 31(6), pp.777-786.

43. Liu E and Page J.E. Optimized cDNA libraries for virus-induced gene silencing (VIGS) using tobacco rattle virus. Plant methods, 2008; 1-13.

44. Lu R., Malcuit I., Moffett P., Ruiz M.T., Peart J., Wu A.J., Rathjen J.P., Bendahmane A., Day L. and Baulcombe D.C. High throughput virus induced gene silencing implicates heat shock protein 90 in plant disease resistance. The EMBO journal, 2003; 5690-5699.

45. Dong, Y., Burch-Smith, T.M., Liu, Y., Mamillapalli, P. and Dinesh-Kumar, S.P., 2007. A ligation-independent cloning tobacco rattle virus vector for high-throughput virus-induced gene silencing identifies roles for NbMADS4-1 and-2 in floral development. Plant physiology, 145(4), pp.1161-1170.

46. Anand A., Vaghchhipawala Z., Ryu C.M., Kang L., Wang K., del-Pozo O., Martin G.B. and Mysore K.S. Identification and characterization of plant genes involved in Agrobacteriummediated plant transformation by virus-induced gene silencing. Molecular Plant-Microbe Interactions, 2007; 41-52.

47. Gao S., Qu J., Chua N.H. and Ye J. A new strain of Indian cassava mosaic virus causes a mosaic disease in the biodiesel crop Jatropha curcas. Archives of virology, 2010; 607-612.

48. Wieczorek P., Budziszewska M. and ObrêpalskaStêplowska A. Construction of infectious clones of tomato torrado virus and their delivery by agroinfiltration. Archives of virology, 2015; 517-521

49. Usharani K.S., Periasamy M. and Malathi V.G. Studies on the activity of a bidirectional promoter of Mungbean yellow mosaic India virus by agroinfiltration. Virus research, 2006; 154-162.

50. Jacob SS, Vanitharani R, Karthikeyan AS, Chinchore Y, Thillaichidambaram P, Veluthambi K. Mungbean yellow mosaic virusVi Agroinfection by codelivery of DNA A and DNA B from one Agrobacterium strain. Plant Dis 2003; 247-251.

51. Sudha M., Karthikeyan A., Nagarajan P., Raveendran M., Senthil N., Pandiyan M., Angappan K., Ramalingam J., Bharathi M., Rabindran R. and Veluthambi K. Screening of mungbean (Vigna radiata) germplasm for resistance to Mungbean yellow mosaic virus using agroinoculation. Canadian J plant pathol. 
$2013 ; 424-430$

52. Kil E.J., Byun H.S., Kim S., Kim J., Park J., Cho S., Yang D.C., Lee K.Y., Choi H.S., Kim J.K. and Lee S. Sweet pepper confirmed as a reservoir host for tomato yellow leaf curl virus by both agroinoculation and whitefly-mediated inoculation. Archives of virology, 2014; 2387-2395.

53. Koeda S., Homma K., Tanaka Y., Onizaki D., Kesumawati E., Zakaria S. and Kanzaki
S., Inoculation of capsicums with Pepper yellow leaf curl Indonesia virus by combining agroinoculation and grafting. The Horticulture Journal, 2018; 364-371.

54. Kheyr Pour A., Gronenborn B. and Czosner H. Agroinocu.lation of tomato yellow leaf curl virus (TYLCV) overcomes the virus resistance of wild Lycopersicon species. Plant Breeding. 1994;228233. 